\title{
Dyned Programme as Computer Assisted Language Learning (CALL) for University Students: A Perception and Its Impact
}

\author{
https://doi.org/10.3991/ijet.v14i13.10448 \\ Entika Fani Prastikawati \\ Universitas PGRI Semarang, Semarang, Indonesia \\ entikafani@upgris.ac.id
}

\begin{abstract}
This paper explores the student's perception on the application of Dyned Programme as Computer Assisted Language Learning (CALL) in English department of Universitas PGRI Semarang, Indonesia. This study is descriptive qualitative. Otherwise, it needs the statistical data in calculating the result percentage. It took 85 students of the first semester students who have already joined Integrated Course (IC) as the sample. IC is a subject which involves ICT-based learning. In this case, Dyned Programme is the ICT-based learning used as CALL. The result of this study shows that the students are satisfied with ICT facilities provided as the media in English teaching and learning. In addition, the use of Dyned Programme in English teaching and learning is well-accepted by the students. Moreover, it comes to the students' perception that shows us how important the media of ICT in English teaching learning process in order to make the students interest in learning English.
\end{abstract}

Keywords—Dyned Programme, CALL, English teaching and learning

\section{$1 \quad$ Introduction}

In Indonesian, English plays an important role of modernization development where it is needed in every single part of living. It has become essential for finding good job prospects. Thus, it made many contributions in education, economic, politic, law etc. In education, English has been encouraged to help students for communicating in the global life. This condition asks some educational institutions insert English as a subject taught to young learners. They assume that starting learning English as soon as possible is good.According to [1], English language is one of themost difficult subjects. [2] states that early childhood is a precious period when children get their most rapid performance in terms of emotional, physical, cognitive and language development. Some educators then assumed the teaching English to young learners is easier than adults.

The different characteristic of learning between young learners and adults asks the teachers to create a different teaching and learning process. Teaching English for young learners needs a concrete example to give a better understanding. As it is 
supported by [3] says children of 7 - 12 years of age are in concrete operational level of cognitive development. Meanwhile, teaching English for adults need more than concrete examples. Teachers need to provide the media which is in line with students' era. Using media in teaching and learning process can arouse new interest, motivationn, stimulus and also bring positive effect for students. [4] stated English teachers should use media in their teaching and learning process and the class will be more meaningful and enjoyable.

In university level, teaching English as a foreign language for adult learners needs more creative and innovative teaching and learning process. They are students who live in digital era nowadays. [5] said that curriculum needs to be rescued from traditional behaviourist approach domination and cognitiveconstructivist approach should be introduced to the system, which is today internationally accepted and fastgrowing model in education systems. It then leads the teachers to provide Internet based learning. ICT is currently being used in education to assist students to learn more effectively and help teachers to do administrative tasks more efficiently [6]. In addition, IT is commonly related as how computers and the Internet can best be harnessed to improve the efficiency and effectiveness of the process of teaching and learning in education field [7]. It plays important role in teaching and learning process in this globalization era because it has transformative effects on education to facilitate the acquisition of knowledge. In addition, [8] explained that ICT is considered as one of the pillars upon which quality education for all can indeed become a reality, because of its unique capacity to bring the world together,even the most remote and disadvantaged of communities.In short, Information and Communication Technology (ICT) has positive impacts. It conveys information in different way such as by multimedia that can make class more interesting.Applying ICT is not limited by place and time. Technology helps teachers and students to broke the limitation of distance. It can access a wide information. [9] indicates that this technology also provides information more quickly when required and it is easily accessible for educational purposes, therefore,learners who grow up in an ICT rich environment are exposed to opportunities to experience and develop skills through its use in and outside the classroom.According to [10], ICT can also play various instructional roles such as make the learners feel more relax to learn the various topics and task, and also make the learners active because they learn by applying the technology to a task rather than by being directly "instructed" by the technology. ICT provides teachers and students to enable for sharing information each others.Accordingly, effective teaching is influenced by the way teachers use ICT tools in the teaching and the learning process and not only how they tools functions [11]. [12] added that using ICT constructively will increase critical thinking for learners, encourages small group activities as well encouraging cooperation between students and teachers. It is one of factors that make a must for ICT development in education. It improves the quality of human and can compete in technology base. In education, media are the systems that teachers and learners represent the knowledge besides the technologies are the tools to share that knowledge.

One of media that used ICT is dyned course. Dyned course is media which teachers and students do not have to meet face to face in giving learning material. 
They need internet access and computer. It creates interaction in teaching learning process effectively. In fact, we are living in multimedia era which internet and world wide web are the prior to complete our needs in many aspects. It helps students as additional practice to enhance their English language learning.

According to [13], the Computer Assisted Language Learning(CALL) software which have been designed for the purpose of language teaching despite other tools such as the Internet, e-mail, and others also promote student-centered language learning and help students develop their communicative skills as well.Meanwhile, [14] describes CALL as complex and dynamic, adding a new dimension to "the already multifaceted domain of second language learning". Teachers must be aware of the impact of technology on education and the required changes to enhance their teaching. Meanwhile, students take responsibility for choosing their own choice to achieve maximal result. According to [15], one of CALL'sadvantages over the traditional classroom is the increased number of opportunities for students to interact with the material. It provides much time for learning in or outside classroom. It cannot replace the face-to-face interaction.One challenge of implementing CALL is that the teachers cannot easily access the learning that is taking place while students are using technology. [16] asserts that the use of technology distances the teacher from the learning process; consequently, the teacher does not have direct knowledge of the learners' strategies and working styles. The positive result of teaching learning is the proof to face that challenge. The positive impact of CALL refers to positivegrowth in areas other than language learning potential [17]. Positive impact may contribute to interest in the target culture and a willingness to communicate in the second language.

In education at university, choosing an appropriate media is important to achieve the purpose of teaching and learning process. In this study, the reseacher discusses perception of students of Universitas PGRI Semarang for applying Dyned programme as Computer Assisted Language Learning (CALL) and the impacts of it.

\section{Related Works}

\subsection{Teaching Media}

In teaching English, teacher must be aware of the age of the students in learning language. Students of different are have different competence, needs or characteristics. It can be made as consideration for teachers in choosing an appropriate way to convey the material. [18] said that media is a human, material, or something that construct students to get knowledge. Media is one of tool that carries message and it can cordinate teaching and learning process. [19] observed the following information retention levels from different modes of lesson delivery. Reading alone effects $(10 \%)$, hearing (lectures) $(20 \%)$, seeing visual aids $(30 \%)$, seeing visual and hearing lectures (50\%), doing (acting onlessons) $(80 \%)$ and acting in lessons and saying $(90 \%)$. A combination of models of delivery and learning media therefore enhances lesson effectiveness.It helps students to interest of the lesson and 
also it leads students' attention.In traditional language teaching methodologies, teachers teach facts from books. The teachers are seen as the main source of knowledge to the students. Media is used to allay students' bored during the lesson. If students feel fun, they will enjoy the teaching learning process and they understand the material that is given by the teacher. Teaching learning process is the communication process, so the media is an important thing as one of learning system components. Without media, communication will not happen and the teaching learning process will not be optimum.

[4] stated that the major problems of teaching English in class seem that learners are not interested in studying. In order to make them interested in learning and make them motivate in learning, it is suggested that English teachers should use media in their teaching and learning process and the class will be more meaningful and enjoyable. Media can also serve an important motivator in the language teaching process. Teaching using media can extend the opportunities for learning far greater than chalk and talk [19]. The learner is able to piece together patterns of new concepts using multiple sensory dialogues. These senses are not always stimulated at the same time. The stimulation depends on the media that teacher uses. In addition, media is used to create an interactive learning to the students. [20] explained that:

Instructional activities must bearranged so that students have appropriate opportunities to engage in meaningful learning (as opposed to rote learning). Academic engagement will be evident when students are on task, focused on important issues and consciously striving to learn. Students need to be seriously engaged in learning in order to achieve deep understanding. Academic engagement is closely linked to students commitment and motivation and to the nature of interactions within class room social systems

An interactive learning is a learning that giving chance for the students to deliver their idea about the material that they are learning. It makes class become more active.Media has functions to be an instruction for the students and as learning sources.

According to [21], there are three kinds of media, as follows:

Print media: They include books, journals, magazines, newspapers, workbooks, and textbooks

Non print media: They include projected and non-projected media

Projected media requires light source for projection, such as film projector slides, and so on. Meanwhile, non-projected media do not require light source. They include 3 dimensional objects, 2 dimensional objects, prints, charts, models and so on.

Electronic media: They include audio media, Visual media \& Audio

Audio media carries sounds alone, such as audio tapes, record player. Visual media is the one that can be seen, such as television, computer, and whiteboard. Meanwhile, audio-visual refers to those instructional materials which provide learners with audio and visual experiences by appearing to the hearing and seeing senses at the same time, for example television, video tapes, and closed-circuit television (CCTV). 


\subsection{ICT in English Teaching and Learning Process}

Nowdays, we are living in the digital technology and the millennium of the internet or the World Wide Web (WWW). Technology has increasingly becomeavital element for firms to compete and develop. ICT stands for Information and Communication Technology. Information and Communication Technology (ICT) is the terminology that embraces two aspects such as technology of information and technology of communication. Technology of information is thing that related to the process in regulating information. Meanwhile, technology of communication belongs to the tools that help the process of transfering the data to one device to other device. So, technology of information and technology of communication are two concepts that can not be separated.Information and communication technology (ICT) has changed many aspects such as education, business, trade, science etc. In fact, ICT has many beneficial luck in education. For example, ITC can be a tool to present material in many different ways such as pictures, tables, graph or other multimedia that can make class more interesting because the students learn by applying the technology. According to [22], ICT provides a variety of language opportunities for students to learn language. In addition ICT in education can enhance learning environment for learners, act as a powerful tool to supplement teachers classroom instructions, use as an administrative tool for teachers and administrators, increase access to education and inclusive education in schools [23]. In the same way, [24] actually confirms thatICT is an importanttool to enhance teaching and learning that anEnglish Language teacher can make use of in teaching the subject. The internet and the World Wide Web was able to provide supplemental language activities which can help students with additional practices in specific areas of language. It helps them to enhance their English language learning. Also, teachers need knowledge to arrange lesson plan to intergrate ICT into their class activities.

There are many challenges in applying ICT. This is because of the difference in age, learning styles, limited skills, lack of experience in technology. [22] conducted a study on Community college students' barrier to participate in web-based course. She explained that the barriers identified to participants in Web-based courses include the inability to have face-to-face interactions with the instructor and classmates, the inability to have questions answered immediately. Other barriers include the incompatibility with student learning styles and Web-based courses, lack of understanding of Web based courses, the perceived lack of structure of Web-based courses, the quality of Web-based courses, lack of personal motivation, and concerns with technology.

[25] pointed out that the use of ICT has positive effects on foreign language teaching learning, as follows:

- We can get the required information within a fraction of second

- Learners become more innovative with the help of e-learning

- ICT provides the information to the students which will be useful for them to compete with this co mpet it ive world.

- English lessons that incorporate multimedia applications can exert powerful motivation and provide bored students with exciting new ways to learn 
- ICT can make students and teachers to work with current and authentic sources

- ICT ameliorates the learner's interaction, verbalization involvementin group collaborative learning.

- Students can learn independently

- With ICT pictorial description is available.

They also explained that there are some disadvantages of using ICT in education learning, as follows:

- Students get short span of attention because of the ICT in language learning

- Online learning cannot offer human interaction

- Students may open or log on to the unnecessary websites to play games or to watch movies etc

- Intenserequirement for self-discipline and self direction

- Goodinfrastructure and trained man power is required to use the ICT tools in teaching and learning

- Communicationis taking place between learners

- Theteacher is only a mediator.

\subsection{Dyned Programme}

Dyned programme stands for Dynamic Education programme. It is a kind of English language teaching software. Dyned was founded in 1987 by the former director of the total immersion program at the Language Institute of Japan and a team of engineers. Dyned's founders created the world's first interactive multimedia language learning CD-ROM in 1988 and received a U.S. patent for this invention in 1991 [26]. In addition, [27] explained that Dyned (Dynamic Education) is a courseware programme that needs to be installed on a network server. It is a program of software that is designed to help English language learners aged between 11-18 to get success in learning English. Dyned is used in many educational institutions from schools to colleges and universities for the learning of the English language [28]. In the same way, [29] explained that Dyned's research-based courses cover all proficiency levels and include a range of age-appropriate courses, from kids in school to adults in leading corporations. Students are introduced to new language as their level increases. It will strengthen the motivation of the teaching and learning process of the English language.

\section{Research Methodology}

\subsection{Research Design}

This research belongs to descriptive qualitative research. Statistical data is also used to compute the percentage of data analysis. The population is the first semester students of English department who have joined integrated course subject. It is the 
subject which uses Dyned programme (ICT-based learning). Meanwhile, the sample is 85 students of the first semester. Instrument used in this research was questionnaire which was uploaded on www.surveymonkey.com. Then the data was analyzed using Beta analyzer in the form of diagram.

\subsection{Population}

The population in this research is the first semester students of University of PGRI Semarang. The reseacher decided that population because those students have been given subject "Integrated Course" with using "Dyned Course". The sample is 85 students of the first semester.

\section{$4 \quad$ Research Findings and Discussion}

\subsection{Research Findings}

ICT Facility Availability: The result of this research proves that the ICT facility availability that given by University of PGRI Semarang had been fulfilled students's necessary especially in learning English. Here the result of students' responses in questionairre.Based on the questionnaire 3 and 5 , below is the students' response on ICT facility availability provided by university.

Dyned

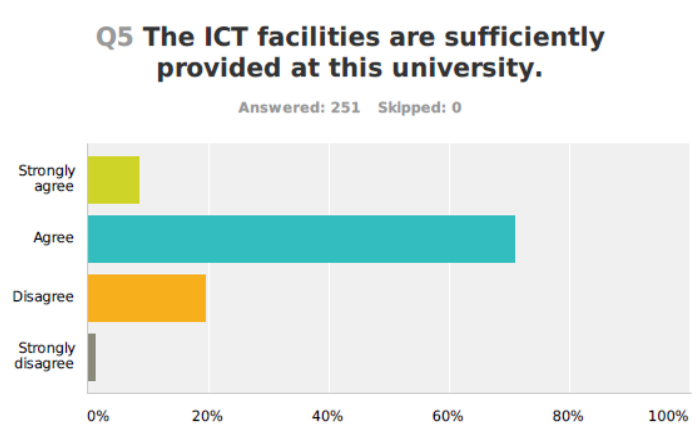

\begin{tabular}{l|lr}
\hline Answer Choices & Responses & \\
\hline Strongly agree & $\mathbf{8 . 3 7 \%}$ & 21 \\
\hline Agree & $\mathbf{7 0 . 9 2 \%}$ & 178 \\
\hline Disagree & $\mathbf{1 9 . 5 2} \%$ & 49 \\
\hline Strongly disagree & $\mathbf{1 . 2 0 \%}$ & 3 \\
\hline Total & & 251 \\
\hline
\end{tabular}

Fig. 1. ICT Facilities Provided at University 
It has been stated in figure 1 that $70.92 \%$ students agree if the facilities provided are sufficient. Thus, based on figure 2 below, it shows that $69,32 \%$ students agree if ICT facilities at university have met the leaning needs of them.

$$
\text { Dyned }
$$

Q3 The ICT facilities at this university meet the leaning needs of the students
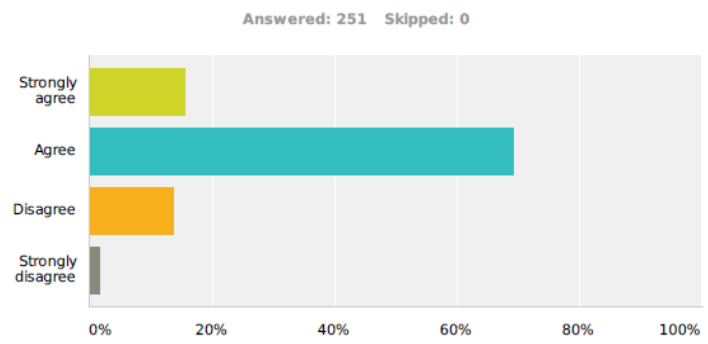

\begin{tabular}{l|lr}
\hline Answer Choices & Responses & \\
\hline Strongly agree & $\mathbf{1 5 . 5 4 \%}$ & 39 \\
\hline Agree & $\mathbf{6 9 . 3 2} \%$ & 174 \\
\hline Disagree & $\mathbf{1 3 . 5 5 \%}$ & 34 \\
\hline Strongly disagree & $\mathbf{1 . 5 9 \%}$ & 4 \\
\hline Total & & 251 \\
\hline
\end{tabular}

Fig. 2. shows that ICT had been fulfilled the students' necessary in learning at this university.

From two questions in the questionairre can be concluded that students explain that their learning necessary had been fulfilled. Many students who agree with applying of ICT is the proof of the positive impact of ICT.

Students' perception of applying ICT in learning English: Eight questions in questionairre below will show the students' opinion or students' perception in applying ICT in learning English.

From those questions, it will be divided into two things. Those are applying ICT in general using for learning English and applying Dyned Courseware in learning English especially in Integrated Course subject. Here the result of each question that had been answered by students. 
Dyned

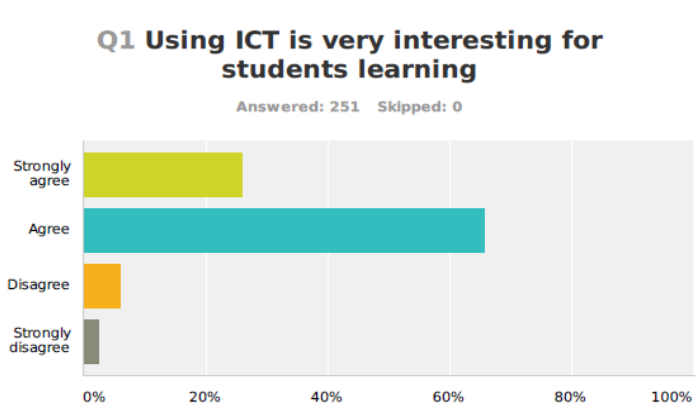

\begin{tabular}{l|lr}
\hline Answer Choices & Responses & \\
\hline Strongly agree & $\mathbf{2 5 . 9 0 \%}$ & 65 \\
\hline Agree & $\mathbf{6 5 . 7 4 \%}$ & 165 \\
\hline Disagree & $\mathbf{5 . 9 8} \%$ & 15 \\
\hline Strongly disagree & $\mathbf{2 . 3 9} \%$ & 6 \\
\hline Total & & 251 \\
\hline
\end{tabular}

Fig. 3. The interesting of using ICT in learning English

From the table above (table from first question) shows that students are satisfied and agree $(65.74 \%)$ that ICT becomes an interesting media in learning English. Meanwhile, 25.90\% students really agree with that statement. Also, 5.98\% students do not agree and $2.39 \%$ students really do not agree. From those results show that students are interested in learning with using ICT as a media of learning English.

Dyned

\section{Q2 ICT is very important for learning} English.

Answered: 251 Skipped: 0

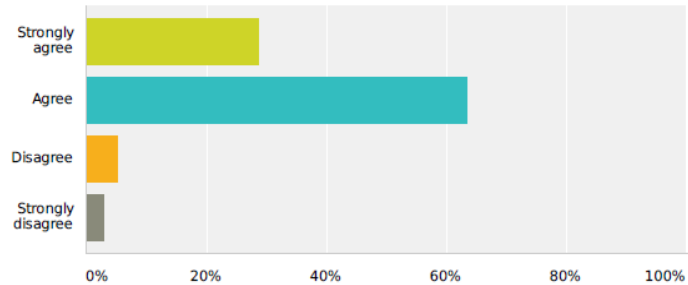

\begin{tabular}{l|lr}
\hline Answer Choices & Responses & \\
\hline Strongly agree & $\mathbf{2 8 . 6 9 \%}$ & 72 \\
\hline Agree & $\mathbf{6 3 . 3 5 \%}$ & 159 \\
\hline Disagree & $\mathbf{5 . 1 8} \%$ & 13 \\
\hline Strongly disagree & $\mathbf{2 . 7 9 \%}$ & 7 \\
\hline Total & & 251 \\
\hline
\end{tabular}

Fig. 4. The importance of applying ICT in learning English 
The next question in that questionairre is about the importance of using ICT in learning English. The result shows there are $63,35 \%$ students who agree. Meanwhile28,69\% students really agree. There are only $5.18 \%$ and $2.79 \%$ students who says that using ICT is needed.
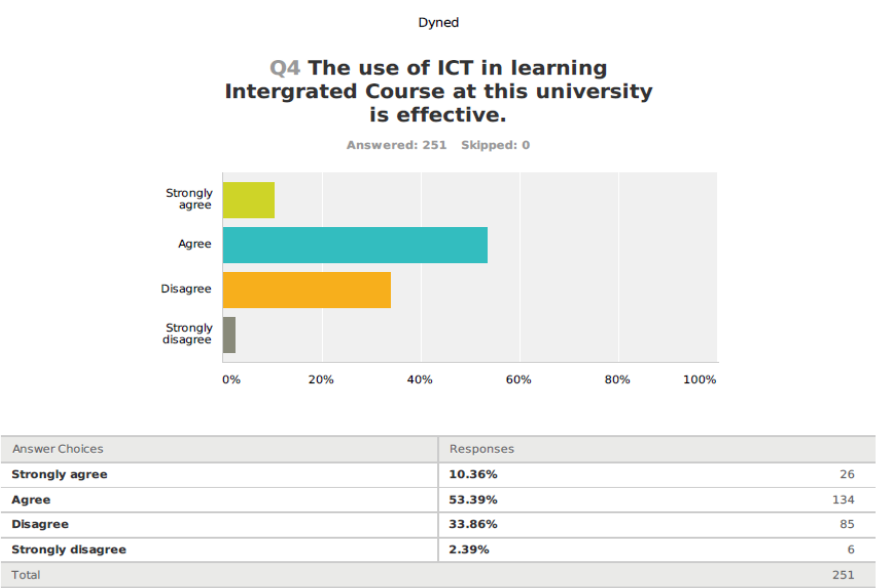

Fig. 5. The effectiveness of the use of ICT in learning Integrated Course

The fourth question is about applying ICT in the Integrated Course subject. The reseacher wants to know the effectiveness of applying ICT in Integrated Course subject. Based on syllabus of Integrated Course, that subject includes four skills in English, such as listening, speaking, reading and writing. The students' answers show that most of them agreed $(53,39 \%)$. On the other hand, the percentage of students who do not agree is significant $(33,86 \%)$. That percentage is significant if we compare with the result of percentage from students who really agree $(10,36 \%)$.
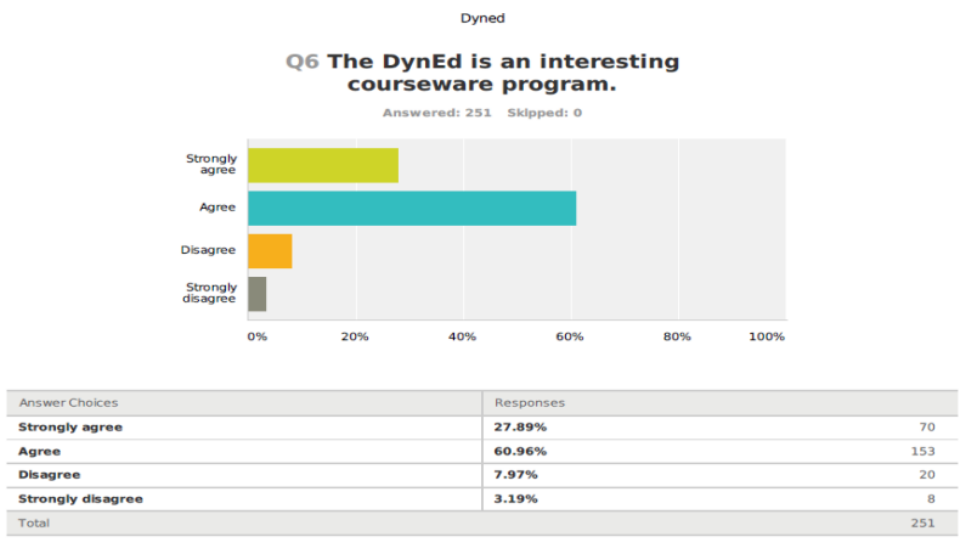

Fig. 6. The interesting courseware of Dyned programme 
The sixth question is given to know whether Dyned Courseware in Integrated Course is interesting or not for students. The result in the table above describes that students are interested in applying Dyned Course (60,96\%). Meanwhile, $27.89 \%$ students agree that Dyned Course is really interesting. On the other side, $7.97 \%$ and $3.19 \%$ show that Dyned Course is not interesting.In general, data above shows that Dyned Course is an interesting for students.

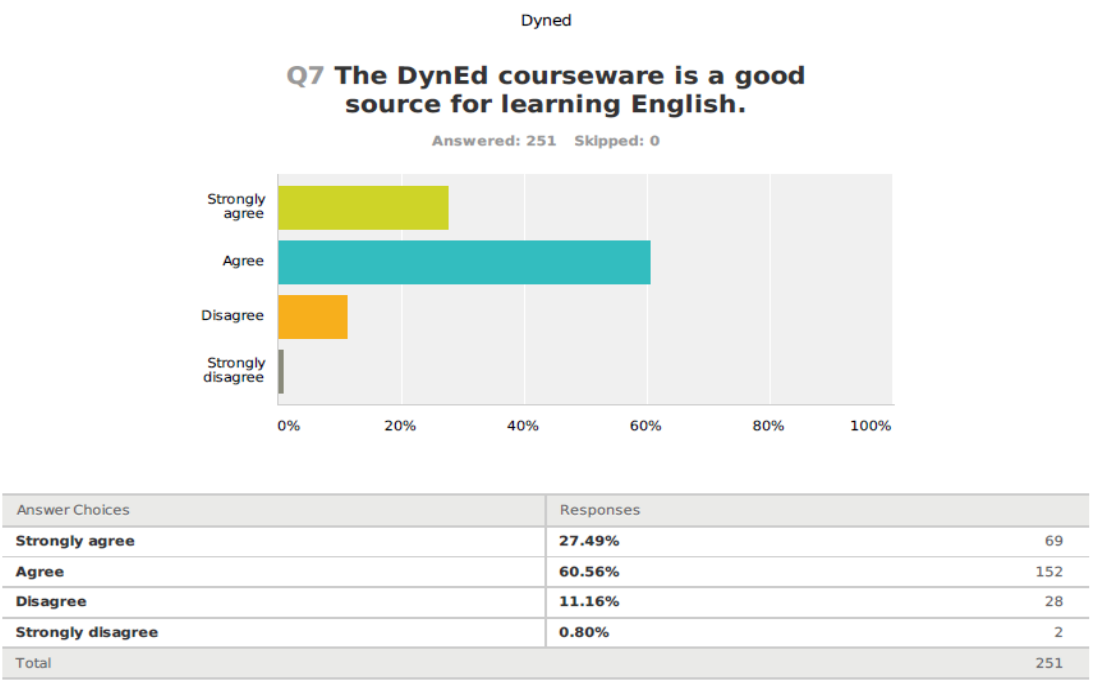

Fig. 7. Dyned programme is as suitable English learning source.

In the seventh question table in survey monkey contains about Dyned Courseware as the suitable English learning source.From the table above explains that $60,56 \%$ students really agree that Dyned is the suitable English learning source. Also, $27.49 \%$ students agree that Dyned is the suitable English learning source. Meanwhile, $11.16 \%$ students do not agree if Dyned is as the suitable learning source in English. $0.80 \%$ students also really do not agree if Dyned is used as good learning source in learning English. 

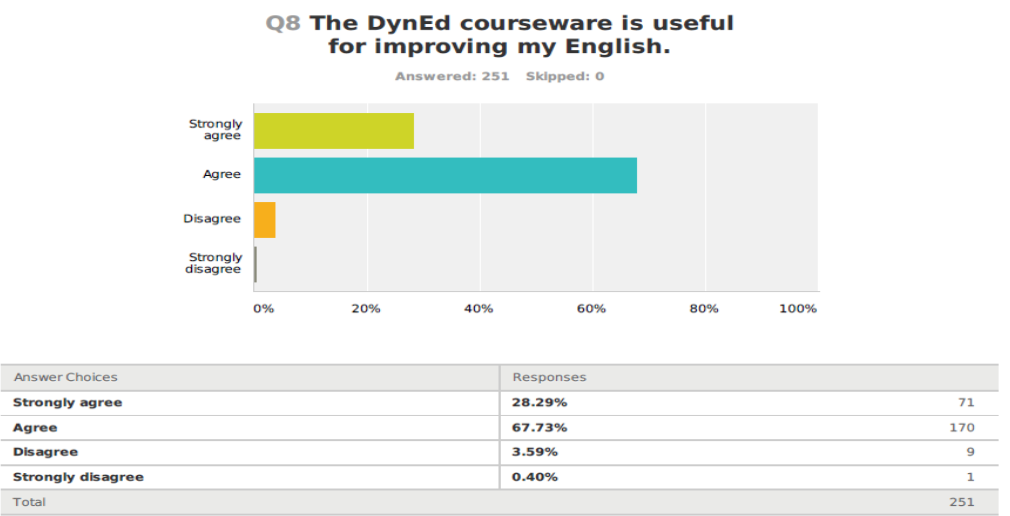

Fig. 8. Shows the data of usefulness of Dyned courseware for improving students' English knowledge

As the previous chapters in this research, the researcher wants to know whether Dyned Courseware gives positive impacts in improving the students' ability in English. The result explains that $67,73 \%$ students agree that Dyned Courseware gives advantages in improving the students' ability in English. That result is the proof that applying Dyned Courseware is useful in improving the students' ability in English.

$28.29 \%$ students really agree that Dyned Courseware is suitable in improving their ability in English. In contrast, 3.59\% students are disagree with that statement and $0.40 \%$ students are really disagree if Dyned Courseware is useful in improving their ability in English.

Dyned
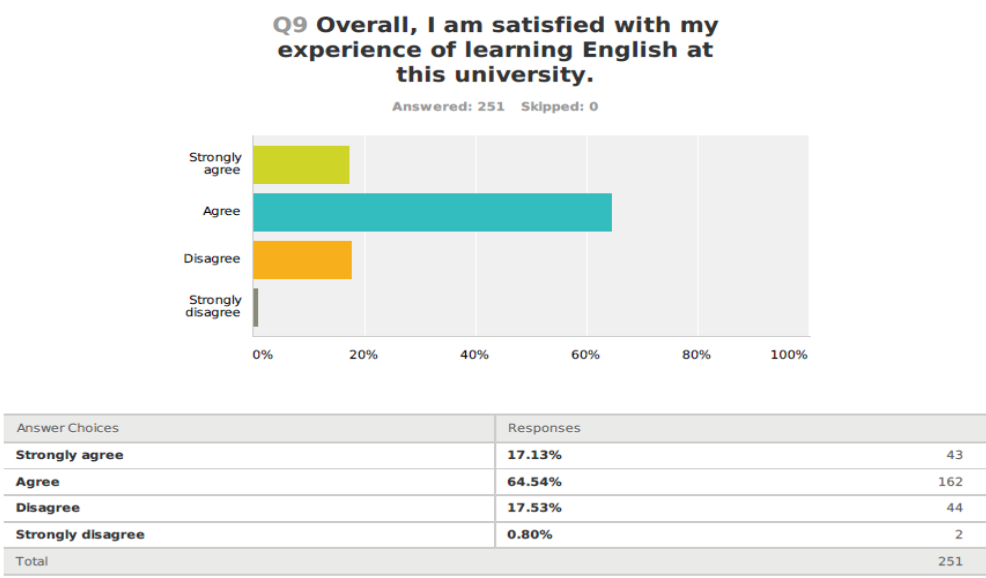

Fig. 9. Students' satisfaction of learning English at the University of PGRI Semarang 
The table above describes the students' satisfied in learning English at this university. There are $64,54 \%$ students who feel satisfied with experience that they find during their study English in this university. In addition, $17.13 \%$ students really feel satisfied. On the other side, $17.53 \%$ students are not satisfied and $0.80 \%$ students are not very satisfied. Over all the result of table Q9 explains that students are satisfied with their experience in learning English at University of PGRI Semarang.
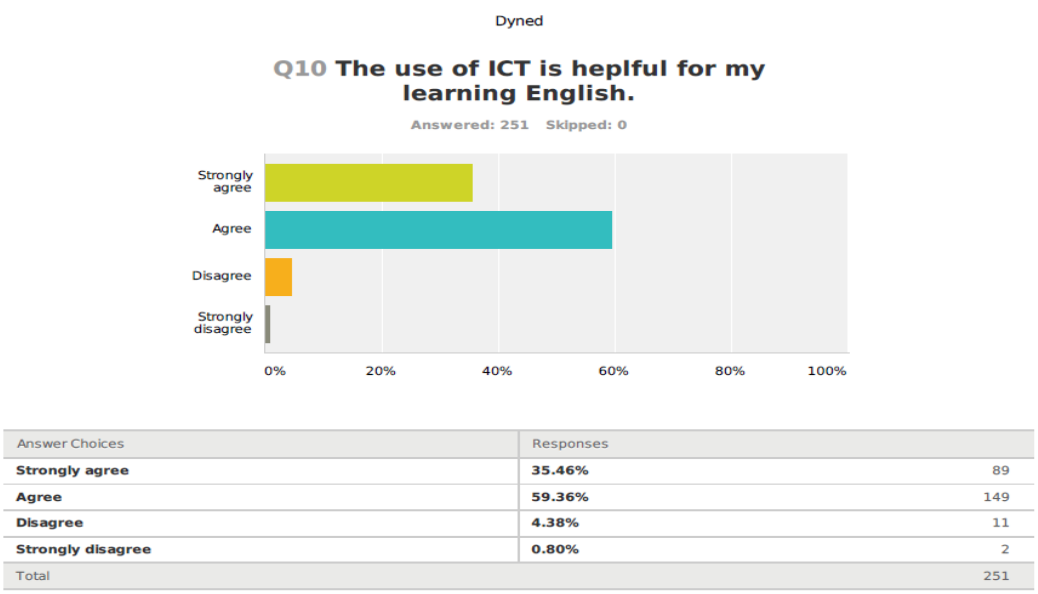

Fig. 10.The data describes that helpfulness of using ICT in learning English

The purpose of this research is finding the usefulness of ICT in learning English at this university. So, this survey gives some questions whether using ICT can be helpful and bring benefits for the students. After doing survey, the reseacher got the data. There are 59,36\% students who said that they feel helpful of using ICT in learning English at this university. At the same way, there are $35.46 \%$ students who really agree if ICT helps them in learning English. In contrast, there are $4.38 \%$ students said that ICT did not help them in learning English and $0.80 \%$ students are very disagree.

\subsection{Discussion}

The purpose of this research is exploring the students' perception on the application of Dyned Programme as Computer Assisted Language Learning (CALL) in English Department of Universitas PGRI Semarang, Indonesia. The result of this research shows that the students are satisfied with ICT facilities provided as the media in English teaching and learning. Sample that had been taken represents the population. From the students' response, there are three main things that become reference. They are the availability of ICT facility at the university, students' proclivity with technology in learning and the importance of applying ICT in teaching learning process.

The reseacher got the data of the availbility of ICT in the University of PGRI Semarang. There are $70.92 \%$ students agree if the facilities provided are sufficient. In 
addition,the data shows that $69,32 \%$ students agree if ICT facilities at university have met the leaning needs of them. Unfortunately, there are some students who said that ICT doest not satisfy. The cause isfrom the availbility of internet. It is as feedback from the university to improve the fasility of internet access. The university have to give priority to extend internet network. During the experiment, there are some computers that can not be used because they do not connect to internet access.

The second one is students' proclivity with technology in learning English. The data shows that students are satisfied and agree $(65.74 \%)$ that ICT becomes an interesting media in learning English. Meanwhile, $25.90 \%$ students really agree with that statement. They are used to operetare computer and internet. Learning foreign language also used those facilities. In modern learning context, using ICT is the part of that learning itself. On the other side, it is reminding that ICT will not replace teachers or lecturers as one of the source of learning. The attendance of teachers or lecturers is still important for controlling and giving motivation to students. They control the class and give direction during the lesson. Also, they are as motivator for their students for keep struggle during teaching and learning process.

The third perception is importance of applying ICT in teaching learning process. The Dyned programme is a sofware learning English that is used in integrated course. From the data collection, there are 59,36\% students who said that they feel helpful of using ICT in learning English at this university. At the same way, there are $35.46 \%$ students who really agree if ICT helps them in learning English. In contrast, there are 4.38\% students said that ICT did not help them in learning English and 0.80\% students are very disagree.Teaching learning process directly in the class is still important to do despite of applying Dyned programme is enough to convey the material. Learning without teacher has not been applied for students of University of PGRI Semarang of the others university in Indonesia.

\section{Conclusion}

From the result, it can be concluded that:

- The availbility of ICT in University of PGRI Semarang is good. It is proved from the data survey. There are $70.92 \%$ students agree if the facilities provided are sufficient. In addition,it shows that $69,32 \%$ students agree if ICT facilities at university have met the leaning needs of them. It means that they agree that their campus had provided the access of technology.

- Applying ICT in learning English is effective. From the data collection, there are $59,36 \%$ students who said that they feel helpful of using ICT in learning English at this university. At the same way, there are $35.46 \%$ students who really agree if ICT helps them in learning English. 


\section{Acknowledgement}

This study was supported by Universitas PGRI Semarang; English Education Department.

\section{$7 \quad$ References}

[1] Ofsted. (2004). Report: ICT in Schools-The Impact of Government Initiatives. Accessed December 30, 2018. Available at : https://dera.ioe.ac.uk/4855/1/the $\% 20$ impact $\% 20$ of $\% 20$ government $\% 20$ initiatives $\% 20$ prim ary\%20(PDF\%20format).pdf

[2] Er, Suhendan. 2013. "Using Total Physical Response Method in Early Childhood Foreign Language Teaching Environments". Journal Procedia - Social and Behavioral Sciences 93, 1766 - 1768. Available at www.sciencedirect.com (accessed 3/3/2018). https://doi.org/10.1016/j.sbspro.2013.10.113

[3] Simatwa, Enose M.W. (2010). Piaget's Theory of Intellectual Development and its Implication for Instructional Management at Pre-Secondary School Level. Educational Research and Reviews. Vol. 5(7), 366-371

[4] Ruis, Nuhung et al. (2009). Interactional Media. Jakarta: Suplement Module MPGPBERMUTU.

[5] Bullard, J. (2009). Constructivism: Does your practice match your Conceptual framework? Journal of Early Childhood Teacher Education, 24:3, 157-162. https://doi.org/10.1080/1090102030240304

[6] Selwyn, N. (2003). ICT in Non-Formal Youth and Adult Education: Defining Territory. OECD/NCAL International roundtable, Philadelphia. Retrieved September 18, 2008 from http://www.literacy.org/ICTconf/OECD.Selwynfinal.pdf

[7] Ogott, George Otieno and Florence Y. Odera. (2012). Integration of Media and Technology in Teaching and Learning Kiswahili Language in Secondary Schools in Siaya County, Kenya. International Journal of Information and Communication Technology Research, Volume 2 Number 10.Retrieved December 25, 2018. http://esjournals.org/ archive/vol2no10/vol2no10 6.pdf

[8] Ndongfack, M. (2015). Mastery of Active and Shared Learning Processes for TechnoPedagogy (MASLEPT): A Model for Teacher Professional Development on Technology Integration. Creative Education, 6, 32-45. Accessed December 30, 2018. https://file.scirp.org/pdf/CE 2015011409214041.pdf https://doi.org/10.4236/ce.2015.61003

[9] Dang, Xuan Thu. (2011). Factors influencing teachers' use of ICT in language teaching: A case study of Hanoi University, Master's Thesis, Vietnam. International Conference "ICT for Language Learners" 4th Edition". Accessed December 25, 2018. Available at : https://pdfs.semanticscholar.org/87d4/be7ae8e8e34d563422f18d7dc283fc6fcfbe.pdf

[10] Grabe \& Grabe. (2005). Integrating technology for meaningful learning. USA: Houghton Mifflin.

Mishra, P., \& Koehler, M. J. (2006). Technological pedagogical content knowledge: Aframework for teacher knowledge. Teacher College Record, 108(6), 1017-1054. Retrieved December 30, 2018. Available at : http://one2oneheights.pbw orks.com/f/MISHRA PUNYA.pdf https://doi.org/10.1111/j.1467-9620.2006.00684.x Agyei, D. D., \&Voogt, J. (2012). Developing Technological Pedagogical ContentKnowledgein Pre-ServiceMathematicsTeachers, Through Teacher Design 
Teams.Australasian Journal of Educational Technology, 28, 547-564. Accessed December 30, 2018. Available at : https://ajet.org.au/index.php/AJET/article/view/827

https://doi.org/10.14742/ajet.827

[11] Gonglewski, Meloni\& Brandt. (2003). Advantages and Disadvantages of Using Computer Network Technology in Language Teaching. Retrieved January 6, 2019. Available at: http://www.englishtime.us/learningenglish/LearningEnglish.aspx

[12] Hubbard, P. (2009). General Introduction In Computer Assisted Language Learning. New York: Routledge.

[13] Hubbard, P. (2013). Making a Case for Learner Training in Technology Enhanced Language Learning Environments. CALICO Journal, 30(2), 163-178. Accessed 5th, 2019. Available at https://web.stanford.edu/ efs/LT-CALICO-CC.pdf https://doi.org/10.11139/cj.30.2.163-178

[14] Chapelle, C. A. (2008). Computer Assisted Language Learning. Malden, MA:Blackwell Publishing.

[15] Chapelle, C.A. (2001). Computer Applications in Second Language Acquisition.Cambridge: Cambridge University Press.

[16] Arsyad, Azhar. (2013). Media Pembelajaran. Jakarta: Pt Raja GrafindoPersaja.

[17] Oyedele, Victoria. et al. (2013). Using Educational Media and Technology in Teaching and Learning Process : A Case of Trainee Teachers at Africa University. Academic Research International Journal, Vol. 4 No. 1. Accessed December 30, 2018. http://www.savap.org.pk/journals/ARInt./Vol.4(1)/2013(4.1-30).pdf

[18] Roy, Killen. (2003). Effective Teaching Strategies: Lessons from Research \& Practice. Melbourne: Thomson, Social Science Press South.

Omodora and Adu. (2014). Relevance of Educational Media and Multimedia Technology for Effective Service Delivery in Teaching and Learning Processes.IOSR Journal of Research \& Method in Education (IOSR-JRME), Volume 4, Issue. Accessed January 6th, 2019. Available at : https://dera.ioe.ac.uk/4855/1/the \%20impact $\% 20$ of $\% 20$ government $\% 20$ initiatives $\% 20$ prim ary\%20(PDF\%20format).pdf https://doi.org/10.9790/7388-04214851

[19] Yunus, MelorMd. (2007). Malaysian ESL teachers' use of ICT in their classrooms: expectations and realities. RECALL: The Journal of EUROCALL. Vol.9 (1): 79-95.

[20] Jhurree, V. (2005). Technology Integration in Education in Developing Countries: Guidelinesto Policy Makers. International Education Journal [Electronic], 6(4):467483.Accessed December 30, 2018.Available at: http://ehlt.flinders.edu.au/educatio n/iej/articles/v6n4/jhurree/paper.pdf

[21] Gumbo, SD. (2003). Utilization of ICT as tools and resources for teaching and learning at the Midlands State University in Zimbabwe. Proceedings of the 11th annual Conference pp. 47-55.

[22] Ammanni, S. (2016). The Role of ICT in English Language Teaching and Learning. International Journal of Scientific \& Engineering Research, Volume 7, Issue 7. Accessed December 30, 2018. Available at : https://www.ijser.org/researchpaper/THE-ROLE-OFICT-IN-ENGLISH-LANGUAGE-TEACHING-AND-LEARNING.pdf https://doi.org/10.1007/978-3-319-38834-2_18

[23] Stark, K. (2004). English for Success Courseware. TESL-EJ. Volume 8, Number 2

[24] Fichou, D. (2003). Network Requirements. USA: DynEd International.

[25] Marimuthu, R. Soon, G. Y. (2005). The DynED Language Learning Software: To What Extent Does It Subscribe to the ARCS Instructional Model? Malaysian Online Journal of Instructional Technology. 2(3), 9- 16. 
[26] Bas, Gokhan. (2010). Evaluation of DynED Courses Used in Elementary Schools From the Views of Teachers in Turkey. Journal of Language and Linguistic Studies Volume 6, Number 1.

\section{Author}

Entika Fani Prastikawati earned her master degree from State University of Semarang in 2011. She is currently an English lecturer at the English Department of University of PGRI Semarang. She has published article in CELT Journal, Eternal Journal, and presented paper in some international conferences like in ELTLT, CTEFL, TEFLIN, LSC, TEYLN Conferences.

Article submitted 2019-03-11. Resubmitted 2019-05-09. Final acceptance 2019-05-10. Final version published as submitted by the authors. 